\title{
Penjualan Go-Food Dalam Dunia Perusahaan Indonesia Publik Relation
}

\author{
Erduandi \\ Ketatalaksanaan Pelayaran Niaga dan Pelabuhan, Akademi Maritim Bina Bahari Palembang \\ Email : akademimaritimbinabahari@gmail.com
}

\begin{abstract}
ABSTRAK
Penelitian ini membahas bagaimana citra Go-Food di indonesia melalui Marketing Public Relation, rumusan masalahnya adalah bagaimanakah Strategi Marketing Public Relation Go-Food dalam membangun citra perusahaan. Penelitian ini menggunakan pendekatan kualitatif dan jenis penelitian deksriptif dengan metode penelitian studi kasus. Hasil penelitian ini adalah Go-Food dalam membentuk citranya di Palembang melaksanakan strategi marketing public relation dengan melakukan serangkaian kegiatan dalam mewujudkan strateginya adapun. Kegiatan-kegiatan yang dilakukan meliputi: analisis situasi, proses perencanaan, pelaksanaan dan pengevaluasian programprogram yang dapat merangsang keinginan memesan dan kepuasan konsumen. Analisis situasi adalah analisis terhadap keadaan pasar sebelum produk layanan akan diinformasikan . Kemudian hasilnya digunakan dalam perencanaan guna menentukan publik suatu perusahaan. Evaluasi dilakukan untuk mengumpulkan pengetahuan serta pemahaman terhadap hasil pelaksanaan strategi marketing public relation.
\end{abstract}

Kata Kunci : Strategi marketing public relations Go-Food

\section{A. PENDAHULUAN}

Penelitian ini membahas tentang bagaimana pembentukan citra GoFood melalui marketing public relation. Peneliti tertarik untuk meneliti permasalahan ini karena menurut peneliti Go-Food merupakan usaha baru dan fitur Go-Food yang dikembangkan oleh Gojek jelas menguntungkan semua pihak. Bagi konsumen, bisa dimudahkan dalam hal memesan makanan. Bagi gojek, bisa menambah pemasukan dengan banyaknya order yang masuk via GoFood.

Siswanto Sutojo (2004:42) Citra eksklusif, yaitu citra yang dapat ditonjolkan pada perusahaanperusahaan besar. Yang dimaksud eksklusif adalah kemampuan menyajikan berbagai macam manfaat terbaik kepada konsumen dan pelanggan. Sedangkan citra inovatif, yaitu citra yang menonjol karena perusahaan tersebut pandai menyajikan produk baru yang model dan desainnya tidak sama dengan produk sejenis yang beredar di pasaran.

Frank Jefkins (2002:14) mengartikan citra sebagai kesan, gambaran atau impresi yang tepat (sesuai dengan kenyataan yang sebenarnya) mengenai berbagai kebijakan, personel, produk, atau jasajasa suatu organisasi atau perusahaan. Citra adalah seperangkat ide dan kesan Seseoramg terhadap suatu obyek tertentu. Sikap dan tindakan seseorang terhadap suatu obyek akan ditentukan oleh citra obyek tersebut yang menampilkan kondisi terbaiknya. Suatu perusahaan harus melakukan analisis citra dalam mengetahui sejauh mana peranan Publik Relation/PR dalam perusahaan tersebut. 
Definisi citra menurut Kamus Besar Bahasa Indonesia adalah rupa, gambaran, yaitu gambaran yang dimiliki orang banyak mengenai pribadi, perusahaan, organisasi atau produk. Pengertian citra itu sendiri abstrak, tidak nyata, tidak bisa digambarkan secara fisik dan tidak dapat diukur secara matematis, karena citra hanya ada dalam pikiran. Walaupun, demikian wujudnya bisa dirasakan dari hasil penilaian baik atau buruk, seperti penerimaan dan tanggapan baik positif maupun negatif yang datang dari publik (khalayak sasaran) dan masyarakat luas pada umumnya.

\section{B. TINJAUAN PUSTAKA}

Membangun citra perusahaan membutuhkan proses yang panjang, karena citra merupakan semua persepsi yang dibentuk oleh konsumen, dengan cara memproses informasi dari berbagai sumber sepanjang waktu. Citra perusahaan berkaitan serta dengan kepercayaan publiknya terhadap organisasi tersebut. Semakin organisasi dapat menjaga kepercayaan publiknya dengan berbagai macam kegiatan public relation yang dilakukan, maka citra dari organisasi tersebut akan semakin baik. Kepercayaan publik juga dapat dibangun dengan memberikan informasi yang benar dan transparan terhadap publiknya, informasi yang jelas dan transparansi dari organisasi yang benar sesuai kenyataan, tepat sasaran dan menggunakan media yang tepat akan membentuk citra langsung pada publik. Citra senantiasa berhubungan dengan publik atau Khalayak luas. Kesan dan pengetahuan mereka mengenai organisasi akan membentuk citra organisasi tersebut.

Menurut Kazt (Soemirat dan Ardiyanto 2005:78) dalam membentuk sebuah citra perusahaan, diperlukan adanya kegiatan public relation. Public relation telah menjadi bagian penting dalam perusahaan, dan perannya dalam mendukung perusahaan semakin tidak diragukan lagi. Perusahaan yang berorientasi pada laba ataupun nirlaba, tetap menimbulkan kegiatan public relation. Citra adalah cara pihak lain memandang sebuah perusahaan, eseorang, suatu komite, atau suatu aktivitas.

Pengertian public relation secara garis besar adalah strategi perusahaan untuk membangun hubungan baik dengan publik agar bisa mendapatkan opini yang positif dari kalangan masyarakat disekitarnya.

Teguh Meininda, $(1989 ; 36)$ (the british institute of public relationa) "public relation adalah keseluruhan upaya yang dilangsungkan secara terencana dan berkesinambungan dalam rangka menciptakan dan memelihara niat baik dan saling pengertian antara suatu organisasi dengan segenap khalayaknya".

Secara etimologis, public relation terdiri dari dua kata, yaitu public dan relations. Public berarti publik dan relation berarti hubungan-hubungan. Jadi, public relation berarti hubunganhubungan dengan publik. Menurut onong uchjana effendy, (2009:8) dalam buku Dimensi - Dimensi Komunikasi tujuan komunikasi adalah fungsi manajemen dari sikap budi yang terencana dan berkesinambungan yang dengan itu organisasi-organisasi dan lembagalembaga yang bersifat umum dan pribadi berupaya membina pengertian, simpati, dan dukungan dari mereka yang ada kaitannya atau yang mungkin ada hubungannya dengan jalan menilai pendapat umum diantara mereka, untuk mengkorelasikan, sedapat mungkin, kebijaksanaan dan tata cara mereka, yang dengan 
informasi yang berencana dan tersebar luas, mencapai kerjasama yang lebih produktif dan pemenuhan kepentingan bersama yang lebih efisien .(Juliansyah,2008: 1-2).

Begitu erat dan pentingnya kerjasama antara bidang public relation dan marketing, sehingga ada istilah untuk menggabungkan aktivitas keduanya yang disebut dengan marketing public relations (MPR). Secara sederhana marketing public relation berarti kegiatan public relation yang didesain untuk mendukung tercapainya tujuan pemasaran (marketing). Marketing public relations sebagai salah satu alat komunikasi pemasaran sangat berperan di tengahtengah banyaknya pesan promosi yang diterima oleh masyarakat. MPR merupakan sarana untuk mengkomunikasikan keunggulan merek dan sering digunakan dalam periklanan, promosi, dan penjualan perorangan.

Dari segi sejarahnya MPR sesungguhnya sudah mulai dikenal pada kurun waktu 1930-an di Amerika. Nama Edward Bernays, Bapak Public Relation Modern, tercatat sebagai orang yang paling sukses menciptakan berbagai program MPR. Konsep MPR ini dicetuskan pertama kali oleh Thomas L.Haris dalam bukunya marketers guide to public relation, Haris menegaskan bahwa marketing public relation merupakan proses perencanaan dan pengevaluasian program-program yang merangsang pembelian dan kepuasan konsumen melalui komunikasi/penyebaran informasi yang dapat dipercaya melalui kesan-kesan yang menghubungkan perusahaan dan produknya sesuai dengan kebutuhan, keinginan dan kepentingan para konsumen.

Pada era globalisasi ini peran marketing public relation menjadi semakin penting karena itikad baik menjadi suatu bagian dari profesionalisme yang pasti akan terbentuk karena pembentukan simpati konsumen secara efektif dan efisien sudah merupakan keharusan dimana tingkat kompleksitas dan pemuasan kebutuhan nasabah sudah mencapai tingkat yang canggih dalam kegiatan pengemasannya (Saka Abadi,1994; 45).

MPR berperan dalam rangka mencapai tujuan-tujuan organisasi seperti: menumbuh kembangkan kesadaran konsumen terhadap produk yang tengah diluncurkan itu, mendorong antusiasme melalui suatu artikel sponsor tentang kegunaan dan manfaat suatu produk, membangun kesadaran konsumen terhadap citra perusahaan atau manfaat atas produk yang ditawarkan/digunakan.

Pembentukan citra layanan GoFood sangat dibutuhkan, hal ini dikarenakan citra berkaitan erat dengan kepercayaan publik terhadap perusahaan. Marketing public relation sebagai bagian dari public relations suatu perusahaan, juga memiliki fungsi manajemen. Fungsi yang dimaksud adalah membangun serta mempertahankan hubungan antara perusahaan dengan publik dengan menggunakan media massa secara persuasif. Sekalipun mengandung kata marketing, MPR dalam hal ini tidak berusaha menjual produk atau jasa, namun lebih kepada memberi informasi. MPR juga berperan membangun kepercayaan konsumen terhadap citra perusahaan. Dengan demikian, MPR dapat digunakan untuk meneliti citra suatu perusahaan yang mana dalam penelitian ini adalah GOJEK melalui Go-Food nya.

\section{HASIL PENELITIAN}

Go-Food merupakan layanan gojek yang melayani food delivery service di indonesia. Fitur layanan food delivery ini layaknya order di 
sebuah rumah makan atau restaurant. Hanya dengan menggunakan smartphone dan membuka fitur GoFood dalam aplikasi Gojek,konsumen bisa memesan makanan dari restaurant yang sudah bekerja sama dengan gojek. Makanan akan dipesan dan diantar langsung oleh Gojek. Singkatnya, layanan ini sangat mirip dengan layanan delivery order disuatu restaurant. Layanan ini diselenggarakan sebagai suatu kegiatan promosi yang mana diketahui sebagai kegiatan menginformasikan tentang suatu produk yang disajikan oleh distributor ataupun produsen tertentu, dalam hal ini adalah penyaji kuliner. Kegiatan-kegiatan yang dilakukan oleh Go-Food adalah memberikan informasi serta pengenalan terhadap produk kuliner. Hal tersebut merupakan pencapaian sasaran dalam penggunaaan public relations.

"Public relations digunakan dalam perencanaan marketing untuk mencapai sasaran yaitu membantu perusahaan dan nama produknya agar lebih dikenal serta membantu mengenalkan produk baru atau peningkatan produk ".(Soemirat dan Ardianto;2010,154).

Bagi pengusaha kuliner, terutama usaha mikro, kecil, dan menengah (UMKM), yang memiliki budget terbatas untuk mengembangkan layanan delivery order, Go-Food bisa menjadi solusi alternatif yang sangat membantu. Pengusaha UMKM bisa memiliki layanan delivery order tanpa harus menyiapkan atau menggaji SDM untuk delivery, itu artinya Go-Food tidak hanya disediakan bagi pemilik restaurant mewah saja.

Indonesia merupakan suatu negara yang memiliki serta menyajikan berbagai produk kuliner. Karena beragamnya produk makanan tersebut, tidak semua masyarakat mengetahui dan mengenal makanan- makanan serta produk kuliner yang ada secara menyeluruh. Keberadaan Go-Food sebagai bagian dari Gojek diharapkan mampu mengenalkan serta menginformasikan masyarakat atas keberagaman tersebut.

Di Indonesi saat ini ada lebih kurang 250.000 armada roda dua Gojek yang bisa dimanfaatkan sebagai armada layanan food delivery. GoFood berusaha mempromosikan kekayaan kuliner khas indonesia, tercatat lebih dari 37.000 restaurant yang bermitra dengan Go-Food. Sebagai layanan order delivery, GoFood berusaha membantu promosi dan penjualan makanan produk anak negeri. Pengembangan dari layanan ini tidak hanya dari jasa antar beli makanan, yakni juga berusaha mempromosikan usaha masyarakat kecil,seperti pedagang kaki lima yang kita ketahui tidak semua mempunyai jasa delivery makanan.

Di sisi lain Go-Food berusaha hadir sebagai perangsang pertumbuhan konsumen. Hal ini juga difungsikan sebagai solusi atas masalah-masalah konsumen yang ditemukan dalam evaluasi terhadap pasar. Salah satu masalah yang muncul berkaitan dengan food delivery service adalah pengaruh mobilitas masyarakat sebagai konsumen. Kecenderungan masyarakat kota yang memiliki mobilitas tinggi, keterbatasan waktu, dan kebutuhan yang tinggi akan makanan kini mampu teratasi dengan adanya Go-Food. Standar pelayanan yang tinggi dan ketepatan dalam delivery service selalu dijunjung untuk memuaskan para pelanggan. Hal ini dilakukan oleh Gojek melalui layanan Go-Food nya sebagai bagian dari kegiatan marketing public relations.

Go-Food juga berusaha memunculkan citra sebagai "No 1 food delivery" di indonesia. Seperti yang dikatakan Lidya selaku Bussines 
Development dari Go-Food : "citra yang kami tawarkan adalah menjadi layanan pengiriman makanan yang bisa diandalkan dan bisa digunakan oleh orang banyak dan menjadi market leader sesuai tagline nya : No 1 food delivery services in Indonesia".

Go-Food juga menggunakan social media sebagai alat ukur untuk melihat citra mereka di masyarakat. Social media dinilai mampu dijadikan bahan acuan untuk melihat citra di masyarakat karena melihat kecenderungan masyarakat yang sering memberikan tanggapan melalui sosial media. Hal ini merujuk pada pengertian bahwa marketing public relations sebagai bagian dari public relations suatu perusahaan yang menggunakan media secara persuasif untuk membentuk citranya. Oleh karena itu Go-Food selalu memaintanace social medianya untuk membentuk citra perusahaannya di masyarakat. Ke depannya, layanan semacam Go-Food akan semakin penting dalam era digitalisasi, dimana masyarakat semakin menuntut layanan yang praktis dan cepat. Bahkan ada kecenderungan para pengusaha akan berlomba untuk bisa bekerjasama dengan penyedia platform seperti Gojek untuk mendongkrak omset bisnisnya, karena fitur Go-Food yang dikembangkan Gojek ini jelas menguntungkan semua pihak. Bagi konsumen bisa dimudahkan dalam hal memesan makanan. Bagi Gojek, bisa menambah pemasukan dengan banyaknya order yang masuk via Go-Food. Sedangkan bagi pengusaha, ada potensi kenaikan omset dari layanan food delivery. Dengan menggunakan fitur ini masyarakat akan lebih banyak mengenal bisnis makanan yang sedang di geluti lewat media sosial dari usaha yang sedang di promosikan oleh Go-Food.
Dengan adanya layanan GoFood tentunya menjadi peluang besar terutama bagi pelaku UKM untuk menerobos dan menguasai pasar agar produknya makin dikenal minimal di satu kota tertentu. Go-Food menawarkan beberapa keuntungan yaitu:

1. Chanel dan market yang lebih luas telah didownload lebih dari 15 juta kali dan nomor satu di APP Store dan Google Play indonesia. Artinya ada 15 juta orang yang mungkin akan melihat produk yang dijual pada layanan Go-Food.

2. Meningkatkan potensi bisnis. Pastinya dengan channel dan market yang lebih luas, bisnis akan berkembang maju dan lebih pesat.

3. Awareness yang lebih luas. Produk juga akan dipromosikan di aset-aset digital Gojek dan GoFood sendiri seperti facebook, twitter, instagram, email yang memiliki banyak followers.

4. Jangkauan pelanggan yang lebih luas. Didukung dengan banyaknya driver Gojek, produk yang dijual akan menjangkau pelanggan dimanapun mereka berada.

5. Pencarian kata kunci lebih diprioritaskan. Misalnya untuk kata kunci "donat/bakso/bubur" maka akan diprioritaskan untuk penjual yang memiliki produk yang sama.

6. Pengkategorian lebih diprioritaskan. Ketika user masuk ke dalam kategori yang sesuai dengan produk, produknya akan muncul paling atas dengan catatan lokasi nya tidak terlalu jauh dari tempat usahanya.

7. Top picks \& recommended dishes. Bagi pedagang yang penjualannya masuk dalam top 1.000 di kotanya akan secara 
otomatis masuk ke kategori top piks dan recommended dishes.

Dalam pelaksanaannya strategi marketing public relations melalui layanan Go-Food, Gojek melakukan serangkaian kegiatan dalam mewujudkan strateginya tersebut. Kegiatan-kegiatan yang dilakukan meliputi: proses perencanaan, pelaksanaan dan pengevaluasian program-program yang dapat merangsang pembelian dan kepuasan konsumen melalui komunikasi mengenai informasi (Ruslan,2001:246)

Dalam kegiatan tersebut pihak Gojek memanfaatkan perkembangan teknologi saat ini. Salah satunya strategi dalam promosi jasa. Seperti penetapan media periklanan menggunakan media internet, sosial media, brosur, radio, event, media partner, dan juga melalui tradisional marketing seperti publikasi dari mulut ke mulut. Wujud nyata yang dilakukan dalam kegiatan tersebut adalah penyebaran informasi melalui akun sosial media. Hal ini dilakukan dengan cara pembelian data oleh pihak Gojek selaku pengiklan guna menunjang pelaksanaan strategi marketing public relationsnya. Data tersebut kemudian digunakan sebagai link untuk mempromosikan produk layanan GoFood.

Proses yang ada dalam kegiatan tersebut meliputi;

1. Pembelian seluruh data yang telah dikategorisasikan berdasarkan topic atau hal tertentu yang disukai (di like) oleh pengguna Sosial media tertentu yang mengandung fitur (like) serta tersambung dengan jaringan sosial media seperti facebook.

2. Data yang dikategorisasikan tersebut kemudian dicocokan dengan karakteristik produk yang akan di iklankan atau dipromosikan.

3. Kecocokan data tersebut kemudian digunakan sebagai acuan bentuk serta jenis pengiklanan pada Sosial media yang telah terkait.

4. Pada akhirnya pengiklanan produk tersebut disajikan sekaligus disiarkan pada timeline akuk-akun sosial media yang termasuk kategorisasi topic yang diminta oleh Go-Food.

Kegiatan lainnya yang dilakukan oleh Go-Food adalah promosi pengiklanan melalui Sosial media secara langsung. Bentuk nyata kegiatan ini adalah dengan membayar para buzzer yang merupakan beberapa food blogger. Kegiatan ini dimaksudkan agar nantinya para food blogger tersebut menyebarkan informasi tentang Go-Food melalui akun media sosial mereka masingmasing.

Wujud kegiatan selanjutnya yang dilakukan oleh Go-Food dalam kegiatan strategi marketing public relationsnya adalah dalam bentuk endorsment. Hal yang dimaksud disini adalah pemberian royalty yang biasanya berupa voucher ataupun fresh money terhadap public figure yang dapat memunculkan para opinion leader. Royalty tersebut diberikan sebagai bentuk reward atas promosi yang nantinya dilakukan oleh public figure tersebut baik melalui media konvensional maupun akun sosial medianya.

Hal ini mencerminkan peranan marketing public relations yang meliputi:
1. Menumbuh
kembangkan
kesadaran konsumennya terhadap produk yang tengah diluncurkan itu.
2. Membangun kepercayaan konsumen terhadap citra


perusahaan atau manfaat atas produk yang ditawarkan.

3. Mendorong antusiasme melalui suatu artikel sponsor tentang kegunaan dan manfaat suatu produk.

4. Bentuk kegiatan diatas tersebut memberikan dampak munculnya perilaku baru pada konsumen, yakni selain berperan sebagai pengguna produk konsumen juga mempromosikan produk yang digunakannya. Kelebihan dari kegiatan promosi ini yaitu adanya hal yang disebut word of mouth. Kotler \& keller, (2007) mengemukakan bahwa word of mouth communication atau komunikasi dari mulut ke mulut merupakan proses komunikasi yang berupa pemberian rekomendasi baik secara individu maupun kelompok terhadap suatu produk atau jasa yang bertujuan untuk memberikan informasi secara personal.

\section{KESIMPULAN}

Berdasarkan pada pembahasan diatas mengenai strategi marketing public relations Go-Food dalam pembentukan citra perusahaan Gojek dapat ditarik kesimpulan bahwa strategi marketing public relations yang dilakukan oleh Go-Food yaitu dengan memulai penyusunan perencanaan, pelaksanaan dan pengevaluasian program-program yang dapat merangsang pembelian dan kepuasan konsumen melalui komunikasi informasi. Untuk mempromosikan diri, Go-Food melakukan serangkaian kegiatan seperti penyebaran informasi melalui akun sosial media dan kegiatan endorsment yang dilakukan oleh para public figure. Untuk menjalankan strategi marketing public relation yang dilakukan oleh Gojek terlebih dahulu melakukan analisis situasi sasaran pemasaran untuk menerima pelayanan jasa yang ditawarkan.

\section{E. SARAN}

Dari kesimpulan tersebut kami menyarankan agar Public Relation dapat menumbuh kembangkan kesadaran konsumennya terhadap produk yang ada. Kemudian membangun kepercayaan konsumen terhadap citra perusahaan atau manfaat atas produk yang ditawarkan, serta mendorong antusiasme melalui suatu artikel sponsor tentang kegunaan dan manfaat suatu produk.

\section{DAFTAR PUSTAKA}

Abadi, Saka.1994. Marketing Public Relations upaya memenangkan persaingan. Jakarta: Lembaga managemen FEUI.

Effendy, Onang Uchjana. 2009. IImu komunikasi teori dan praktek. Bandung, PT.Remaja Rosda Karya.

Harris, Thomas L Whalen T,Patricia. 2006. The marketers guide to public relations. New York: John Wiley \& Sons,inc.

Kotler, Philip \& Kevin Keller. 2007. Manajemen Pemasaran Jilid 1. Jakarta: PT. Indeks

Marcia dan Mensser. 2010. Perilaku Konsumen dan Pemasaran Strategi. Jakarta: Balai Pustaka.

Ruslan, Rosady. 2002. Kiat dan Strategi Kampanye Public Relation. Jakarta: PT. Raja Grafindo Persada.

Ruslan, Rosady. 2010. Metode Penelitian Public Relations dan Komunikasi. Jakarta: Rajawali Pers. 
Sutisna. 2002. Perilaku Konsumen dan Komunikasi

Pemasaran. Bandung: penerbit PT. Remaja Rosdakarya.

Sutojo, Siswanto. 2004. Membangun Citra Perusahaan. Jakarta: Damar Mulia Pustaka.

Donita. "maju dan berkembang bersama Go-Food". 21 april 2017. http://www.donita.co.id/maju-danberkembang-bersama-go-food/

Majalah, franchise. "memanfaatkan Go-Food sebagai layanan food delivery"01 oktober 2017. http://www.majalahfranchise.com/ article/306/memanfaatkangofood-sebagai-layanan -fooddelivery 